\title{
FAKTOR RISIKO BAYI BERAT LAHIR RENDAH DI RUMAH SAKIT UMUM DAERAH (RSUD) HAJI MAKASSAR
}

\author{
Hatijar $^{凶}$ \\ Program Studi D3 Kebidanan STIKES Husada Mandiri Poso
}

\section{ARTICLE INFO \\ Article history}

Submitted : 2020-01-24

Revised : 2020-01-25

Accepted : 2020-01-31

\section{Keywords: \\ Low Birth Weight Babies Mother's age \\ Nutritional status}

\section{Kata Kunci:}

Bayi Berat Lahir Rendah Umur ibu

Status gizi

\begin{abstract}
Low birth weight babies are babies born with a weight less than 2500 grams. LBW (low birth weight) affects the high mortality rate in infants and is at risk of experiencing obstacles in growth and development. LBW is generally caused due to lack of nutrition and nutritional needs from mother to fetus while pregnant women aged less than 20 years and more than 35 years have the risk of giving birth to LBW. The purpose of this study is to determine the risk factors that cause LBW based on maternal age and nutritional status. The research method used was observational with a cross sectional study approach. The sampling technique was random sampling at the Regional Haji Makassar General Hospital in the January to July 2015 period with a total sample of 65 people. Analysis using the Chi Square Test. The results showed that there was a relationship between maternal age, nutritional status of LBW with a value ( $\mathrm{p}$ value = $0.00<\alpha=0.05$ ). Maternal age and nutritional status are factors that influence low birth weight where the results of the study indicate that there is a relationship between maternal age and nutritional status on the incidence of low birth weight. To reduce the incidence of low birth weight, it is necessary to increase counseling about the causes of low birth weight babies by health workers, especially midwives to pregnant women to prevent the risk of low birth weight birth.

Bayi berat lahir rendah adalah bayi yang lahir dengat berat badan kurang dari 2500 gram. BBLR (Berat Bayi Lahir Rendah) mempengaruhi tingginya angka kematian pada bayi serta berisiko mengalami hambatan dalam tumbuh kembang. BBLR umumnya disebabkan karena kurangnya nutrisi dan kebutuhan gizi dari ibu ke janin sedangkan ibu hamil dengan usia kurang dari 20 tahun dan lebih dari 35 tahun mempunyai resiko melahirkan BBLR. Tujuan dari penelitian ini adalah untuk diketahuinya faktor risiko yang menyebabkan terjadinya BBLR berdasarkan umur ibu dan status gizi. Metode penelitian yang digunakan adalah observasional dengan pendekatan cross sectional study. Teknik pengambilan sampel adalah random sampling di Rumah Sakit Umum Daerah Haji Makassar Periode Januari s.d Juli 2015 dengan jumlah sampel 65 orang. Analisis dengan menggunakan Uji Chi Square. Hasil penelitian menunjukkan bahwa ada hubungan antara umur ibu, status gizi terhadap BBLR dengan nilai ( $\mathrm{p}$ value $=0,00$ $<\alpha=0,05$ ). Umur ibu dan status gizi merupakan faktor yang mempengaruhi berat bayi lahir rendah dimana hasil penelitian menunjukkan bahwa ada hubungan antara umur ibu dan status gizi terhadap kejadian berat bayi lahir rendah. Untuk mengurangi angka kejadian berat lahir rendah perlu ditingkatkan pemberian penyuluhan tentang penyebab terjadinya bayi berat lahir rendah oleh petugas kesehatan khususnya bidan terhadap ibuibu hamil untuk mencegah risiko terjadinya berat bayi lahir rendah.
\end{abstract}

\section{Corresponding Author:}

\section{Hatijar}

Program Studi D3 Kebidanan STIKES Husada Mandiri Poso

Telp. 081322935768

Email: yjharsaja@gmail.com

\section{PENDAHULUAN}

Pembangunan kesehatan adalah bagian integral dari pembangunan nasional. Konsep pembangunan nasional harus berwawasan kesehatan, yaituh yang telah memperhitungkan dengan seksama berbagai dampak positif maupun negatif terhadap kegiatan kesehatan masyarakat. Tujuan pembangunan milenium
2000 - 2015 (Milenium Development Goals/MDgs) adalah menurunkan angka kematian bila termasuk Angka Kematian Bayi (AKB) dan neonatal menjadi 16/1000 kelahiran hidup (Saifuddin AB, 2002). Berdasarkan data World Health Organitation (WHO) tahun 2008 menunjukkan bahwa prevelensi bayi berat lahir rendah (BBLR) diperkirakan 15\% dari seluruh 
kelahiran di dunia, dengan batasan 3,3-38\%, dan lebih sering terjadi di negara-negara berkembang dengan sosial ekonomi rendah. Secara statistik menunjukkan $90 \%$ kejadian bayi berat lahir rendah (BBLR) didapatkan di negara-negara berkembang dan angka kematiannya 35 kali lebih tinggi dibanding pada bayi dengan berat badan lahir di atas 2.500 gram. Berat badan lahir rendah termasuk faktor utama yang mengakibatkan mortalitas dan morbiditas bayi dan anak serta memberikan dampak jangka panjang kehidupan di masa depan (Pantiawati, 2010).

Target Millenium Development Goals sampai dengan tahun 2015 adalah mengurangi angka kematian bayi dan balita sebesar dua per tiga dari tahun 1990 yaitu sebesar 20 per 1000 kelahiran hidup. Angka kematian bayi di Indonesia menurut SDKI 2002 - 2003 adalah $57 \%$ terjadi pada umur dibawah satu bulan. Penyebab tersebut antara lain karena gangguan perinatal dan bayi dengan berat badan lahir rendah. Berat Badan Lahir Rendah (BBLR) dan prematur merupakan penyebab kematian neonatal yang tinggi yaituh sebesar 30,3\%. 2 Neonatal dengan BBLR beresiko mengalami kematian 6,5 kali lebih besar dari pada bayi yang lahir dengan berat badan normal. Dalam siaran persnya Badan PBB untuk masalah anakanak UNICEF menyatakan sejak tahun 1990, angka kematian ibu dan anak Indonesia mengalami penurunan lebih dari setengah setiap tahunnya.

Menurut data Survey Demografi dan Kesehatan Indonesia (SDKI) tahun 2009, angka kejadian BBLR di Indonesia sangat bervariasi antara satu daerah dengan daerah lain,yaitu berkisar antara $9-30 \%$, hasil studi di 7 daerah diperoleh angka multicenter BBLR dengan rentang 2,1 - 17,2\%. Secara nasional berdasarkan analisis lanjut SDKI, angka BBLR sekitar 7,5\%. Angka ini lebih besar dari target yang ditetapkan pada sasaran program perbaikan gizi menuju Indonesia Sehat 2010 yakni $7 \%$. Secara statistik 90\% kejadian BBLR didapatkan di Negara berkembang dan angka kematiannya 35 kali lebih tinggi dibanding pada bayi dengan berat badan lahir lebih dari 2500 gram (Pantiawati, 2010).

Menurut data dari Dinas Kesehatan Provinsi Sulawesi Selatan, pada tahun 2010, jumlah kematian bayi mencapai 534 jiwa, yang disebabkan oleh Pendarahan 1 jiwa $(0,19 \%)$, ikterus 7 jiwa (1,31\%), Tetanus 8 jiwa $(1,50 \%)$,
Sepsis neonatorum 16 jiwa (3,00\%), hipotermi 21 jiwa (3,93\%), Kelainan kongenital 36 jiwa (6,74\%), lain-lain 102 jiwa (19,11\%). BBLR 160 jiwa (29,96\%), dan Asfiksia 183 jiwa (34,27\%) (Profil Dinas Kesehatan Propinsi Sulawesi Selatan, 2010).

Tujuan secara umum penelitian ini adalah untuk diketahuinya faktor risiko terhadap kejadian BBLR. Berdasarkan data diatas menunjukkan betapa besar peranan masalah BBLR terhadap penyebab kematian bayi, dengan melihat berbagai macam faktor yang diduga mempengaruhi kelahiran BBLR dengan ini peneliti hanya membatasi masalah pada faktor umur, status gizi yang diduga dapat mempengaruhi kelahiran BBLR, maka penulis tertarik. Untuk melakukan penelitian mengenai "faktor risiko kejadian bayi berat lahir rendah di Rumah Sakit Umum Daerah (RSUD) Haji Makassar.

\section{METODE PENELITIAN \\ Jenis Penelitian}

Jenis penelitian ini adalah penelitian observasional dengan pendekatan cross sectional study

\section{Lokasi dan Waktu Penelitian}

Penelitian ini dilaksanakan di Rumah Sakit Umum Haji Makassar. Waktu penelitian dilaksanakan pada periode Januari - Juli 2015.

\section{Populasi dan Sampel}

Populasi dalam penelitian ini adalah semua bayi yang lahir di Rumah Sakit Umum Haji Makassar yang kelahirannya tercatat pada buku kohort bayi. Sampel Penelitian ini adalah semua ibu yang mempunyai bayi BBLR di Rumah Sakit Umum Haji Makassar

\section{Teknik Pengambilan Sampel}

Teknik pengambilan sampel yang digunakan dalam penelitian ini adalah teknik (Random Sampling) yaitu pengambilan sampel secara acak yang dilakukan dengan membagikan kuisioner kepada sebagian ibu yang memiliki bayi berat lahir rendah di RSUD Haji Makassar.

\section{Pengolahan dan Analisa Data}

Pengolahan data dilakukan dengan menggunakan komputer dengan program SPSS for Windows. Analisis data yang digunakan adalah analisis Univariat dan Analisis bivariat dibuat untuk meneliti hipotesis penelitian, 
untuk digunakan pada uji stasistik chi square dengan tingkat kemaknaan $\alpha=0,05$.

\section{HASIL PENELITIAN}

Berdasarkan tabel menunjukkan bahwa dari 65 total sampel terdapat 44 orang $(67,7 \%)$ resiko tinggi bayi berat lahir rendah dan 21 orang $(32,3 \%)$ resiko rendah bayi berat lahir rendah.berdasarkan umur ibu dari 65 sampel terdapat resiko tinggi sebanyak 29 orang (44.6\%) dan resiko rendah sebanyak 36 orang $(55.4 \%)$ dan berdasarkan status gizi menunjukkan dari 65 sampel terdapat jumlah resiko tinggi sebanyak 31 orang $(47.7 \%)$ dan resiko rendah sebanyak 34 orang $(52.3 \%)$.

Tabel 1. Distribusi Frekuensi Karakteristik Responden di RSUD Haji Makassar

\begin{tabular}{lcl}
\hline Karakteristik Responden & Frekuensi (n) & Persen (\%) \\
\hline Bayi baru Lahir & & \\
Risiko Tinggi & 44 & 67,7 \\
Risiko Rendah & 21 & 32,3 \\
Umur ibu & & \\
Risiko Tinggi & 29 & 44,6 \\
Risiko Rendah & 36 & 55,4 \\
Status gizi & & \\
Risiko Tinggi & 31 & 47,7 \\
Risiko Rendah & 34 & 52,3 \\
\hline
\end{tabular}

Berdasarakan tabel 2. distribusi frekuensi dari 65 orang bayi yang dilahirkan untuk risiko tinggi dengan bayi berat badan lahir rendah yakni 20 orang (30,8\%), sedangkan untuk risiko rendah dengan bayi berat lahir rendah yakni sebanyak 24 orang $(36,9 \%)$. Berdasarkan hasil analisis statistik dengan menggunakan uji chi square didapatkan nilai $\mathrm{p}=0,000<\alpha=0,05$, maka dapat disimpulkan bahwa hipotesis nol ditolak dan hipotesis alternatif diterima artinya ada hubungan antara umur ibu dengan faktor risiko bayi berat lahir rendah (BBLR).

Tabel 2. Analisis Faktor Risiko BBLR Berdasarkan Umur Ibu di Rumah Sakit Umum Daerah Haji Makassar

\begin{tabular}{|c|c|c|c|c|c|c|c|}
\hline \multirow{3}{*}{ Umur Ibu } & \multicolumn{4}{|c|}{ Berat Badan Lahir Rendah } & \multirow{2}{*}{\multicolumn{2}{|c|}{ Total }} & \multirow{3}{*}{ Nilai p } \\
\hline & \multicolumn{2}{|c|}{ Risiko Tinggi } & \multicolumn{2}{|c|}{ Risiko Rendah } & & & \\
\hline & $\mathbf{n}$ & $\%$ & $\mathbf{n}$ & $\%$ & $\mathbf{n}$ & $\%$ & \\
\hline Risiko Tinggi & 20 & 30,8 & 9 & 13,8 & 29 & 44,6 & \\
\hline Risiko Rendah & 24 & 36,9 & 12 & 18,5 & 36 & 55,4 & 0.000 \\
\hline Jumlah & 44 & 67,7 & 21 & 33,3 & 65 & 100 & \\
\hline
\end{tabular}

Tabel 3. Analisis Faktor Risiko BBLR Berdasarkan Status Gizi Ibu di Rumah Sakit Umum Daerah Haji Makassar

\begin{tabular}{lcccccccc}
\hline & \multicolumn{9}{c}{ Berat Badan Lahir Rendah } & \multirow{2}{*}{ Total } & \multirow{2}{*}{ Nilai p } \\
\cline { 2 - 6 } Status Gizi Ibu & Risiko Tinggi & \multicolumn{2}{c}{ Risiko Rendah } & & & \\
\cline { 2 - 7 } & $\mathbf{n}$ & $\mathbf{\%}$ & $\mathbf{n}$ & $\mathbf{\%}$ & $\mathbf{n}$ & $\mathbf{\%}$ & \\
\hline Risiko Tinggi & 31 & 47,7 & 0 & 0 & 31 & 47,7 & \\
Risiko Rendah & 13 & 20,0 & 21 & 32,3 & 34 & 52,3 & 0.000 \\
Jumlah & 44 & 67,7 & 21 & 32,3 & 65 & 100 & \\
\hline
\end{tabular}


Berdasarkan tabel 3. bahwa dari 65 orang bayi yang dilahirkan untuk resiko tinggi bayi berat badan lahir rendah yakni 31 orang $(47,7 \%)$, sedangkan untuk resiko rendah dengan bayi berat lahir rendah yakni sebanyak 13 orang $(20,0 \%)$. Berdasarkan hasil analisis statistik dengan menggunakan chi square didapatkan nilai $\mathrm{p}=0,000<\alpha=0,05$, maka dapat disimpulkan bahwa hipotesis nol ditolak dan hipotesis alternative diterima artinya ada hubungan antara status gizi ibu dengan faktor risiko bayi berat lahir rendah (BBLR).

\section{PEMBAHASAN}

Setelah dilakukan penelitian mengenai analisis faktor risiko kejadian Bayi Berat Lahir Rendah (BBLR) di Rumah Sakit Umum Daerah Haji Makassar, terdapat 65 kejadian bayi berat lahir rendah. Hal ini dipengaruhi oleh faktor antara lain: umur ibu pada saat kehamilan, status gizi ibu, adapun hasil yang diperoleh dari penelitian ini adalah sebagai berikut:

\section{Hubungan Umur Ibu dengan Kejadian BBLR}

Salah satu faktor risiko terjadinya komplikasi kehamilan dan persalinan adalah usia $<20$ tahun dan > 35 tahun. Dalam kurun waktu reproduksi sehat dikenal bahwa usia aman untuk kehamilan adalah usia $20-35$ tahun. Hasil penelitian dari 65 responden yang mempunyai umur resiko tinggi tetapi mengalami BBLR resiko rendah sebanyak 9 orang $(13,8 \%)$ dan dari 65 responden yang mempunyai umur resiko rendah dan mengalami BBLR risiko tinggi sebanyak 34 orang $(36,9 \%)$, hal ini disebabkan bahwa usia kehamilan kurang dari 37 minggu dan jarak kehamilan dimana bahwa jarak kehamilan kurang dari 2 tahun lebih banyak melahirkan BBLR karena secara biologis berat badan bayi semakin bertambah sesuai dengan umur kehamilan dimana umur kehamilan mempengaruhi kejadian BBLR, semakin pendek masa kehamilan semakin kurang sempurna pertumbuhan alat-alat tubuhnya. Hal ini diperkuat dengan teori (Maryunani, 2009) bahwa usia $<20$ tahun memiliki rahim dan panggul yang belum sempurna dan usia ibu > 35 tahun rahim ibu mulai menurun sehingga melahirkan bayi lahir BBLR. Ibu dengan usia resiko tinggi banyak memerlukan energy.

Berdasarkan data hasil penelitan didapatkan hasil uji satistik dengan nilai $\mathrm{p}=$
$0,000 \geq \alpha=0,05$, maka dapat disimpulkan bahwa Ho ditolak dan Ha diterima artinya ada hubungan antara umur ibu dengan faktor risiko bayi berat lahir rendah (BBLR). Hasil ini sesuai dengan teori (Wiknjosastro, 2009) yang mengemukakan bahwa umur ibu saat hamil mempunyai hubungan erat dengan perkembangan alat-alat reproduksinya. Dimana umur reproduksi yang sehat untuk melahirkan anak adalah antara 20 - 35 tahun.

Hal ini disebabkan karena wanita pada umur < 20 tahun pada umumnya alat reproduksinya secara fisik belum optimal untuk menerima hasil konsepsi, secara psikis umur yang terlalu muda belum siap secara mental dan emosional dalam menghadapi kehamilannya. Pada umur > 35 tahun elastisitas otot-otot reproduksi sudah mengalami kemunduran dalam fungsinya, dimana pembuluh-pembuluh darah uterus juga mengalami perubahan/degeneratif yang nantinya akan menyebabkan aliran darah keuterus terganggu sehingga pada akhirnya mempengaruhi pertumbuhan janin.

Hal ini juga diperkuat dengan penelitian (Sari \& Rahayu, 2017) yang menemukan bahwa terdapat pengaruh kehamilan remaja terhadap bayi berat badan lahir rendah di Rumah Sakit Islam Klaten. Pada penelitian ini diperoleh Nilai Odds Rasio sebesar 0,146 yang berarti bahwa kehamilan remaja lebih berisiko sebesar 0,146 kali terhadap terjadinya berat badan bayi lahir rendah.

\section{Hubungan Status Gizi dengan Kejadian BBLR}

Berdasarkan tabel distribusi frekuensi bahwa hasil penelitian dari 65 orang bayi yang dilahirkan untuk resiko tinggi bayi berat badan lahir rendah yakni 31 orang $(47,7 \%)$, sedangkan untuk resiko rendah dengan bayi berat lahir rendah yakni sebanyak 13 orang $(20,0 \%)$. Berdasarkan hasil analisis statistik dengan menggunakan chi square didapatkan nilai $\mathrm{p}=0,000<\alpha=0,05$, maka dapat disimpulkan bahwa hipotesis nul ditolak dan hipotesis alternatif diterima artinya ada hubungan antara status gizi ibu dengan faktor risiko bayi berat lahir rendah (BBLR).

Ibu hamil salah satu kelompok yang rentan terhadap gangguan gizi, karena selama kehamilan diperlukan berbagai unsur gizi yang jauh lebih banyak. Disamping itu untuk memenuhi kebutuhan ibu sendiri juga 
diperlukan untuk pertumbuhan dan perkembangan janin yang ada dalam kandungan. Oleh sebab itu, jika ibu kurang mengkonsumsi makanan yang bergizi selama kehamilan akan menyebabkan risiko tinggi melahirkan bayi berat lahir rendah.

Dari hasil tabulasi data, terdapat 65 orang bayi yang dilahirkan untuk status gizi risiko rendah dengan bayi berat lahir rendah dengan risiko tinggi yakni sebanyak 13 orang $(20,0 \%)$, hal ini dikarenakan yang mempengaruhi kejadian BBLR bukan hanya status gizi ibu tetapi masih terdapat faktor lainnya. Hal ini sesuai dengan pendapat (Manuaba, 2013) bahwa terdapat beberapa faktor yang mempengaruhi kejadian BBLR yaitu dari ibu meliputi usia, paritas dan jarak kehamilan.

Pendapat lain yang mendukung penelitian ini yaitu sesuai berat badan hamil, sementara wanita kurus akan memiliki risiko tinggi mengalami bayi berat lahir rendah (BBLR) terutama jika tidak mampu untuk mendapatkan cukup berat badan selama kehamilan (Whitney, 2007). Status gizi merupakan salah satu faktor risiko untuk terjadinya kematian, status gizi yang baik pada seseorang akan berkontribusi terhadap kesehatan dan juga kemampuan dalam proses pemulihan. Jika status gizi buruk yang berlangsung secara kronis dapat mempengaruhi hasil akhir kehamilan salah satunya terjadinya bayi berat lahir rendah. Penelitian ini juga diperkuat oleh penelitian (Puspitaningrum, 2018) dimana berdasarkan hasil uji Chi-Square diperoleh hubungan antara status gizi ibu hamil dengan kejadian BBLR di RSIA Annisa Kota Jambi Tahun 2018 (p-value $=0,016$ ).

Hasil penelitian ini juga membuktikan bahwa ibu hamil yang kurang gizi akan cenderung melahirkan bayi yang kurang gizi dengan berat badan bayi kurang dari 2500 gram. Sesuai juga dengan pendapat Peneliti yang lain yang menyatakan bahwa kekurangan gizi pada ibu hamil akan menyebabkan pertumbuhan janin terganggu hingga bayi lahir dengan berat badan lahir rendah (BBLR). Status gizi ibu hamil menurut (Supariasa, I. D. W., Bakri, B,. Fajar, 2001) sangat mempengaruhi pertumbuhan janin dalam kandungan. Apabila status gizi ibu buruk baik sebelum kehamilan mupun selama kehamilan akan menyebabkan bayi berat lahir rendah (BBLR).

\section{KESIMPULAN DAN SARAN}

Dari hasil penelitian dapat disimpulkan bahwa umur ibu dan status gizi merupakan faktor yang mempengaruhi berat bayi lahir rendah dimana hasil penelitian bahwa ada hubungan antara umur ibu dan status gizi terhadap kejadian berat bayi lahir rendah. Untuk mengurangi angka kejadian berat lahir rendah perlu ditingkatkan pemberian penyuluhan tentang penyebab terjadinya bayi berat lahir rendah oleh petugas kesehatan khususnya bidan terhadap ibu-ibu hamil untuk mencegah risiko terjadinya berat bayi lahir rendah.

\section{DAFTAR PUSTAKA}

Manuaba, I. B. G. (2013). Ilmu Kebidanan, Penyakit Kandungan dan Keluarga Berencana untuk Pendidikan Bidan. Jakarta: EGC.

Maryunani, A. (2009). Asuhan Kegawatdaruratan dan Penyulit pada Neonatus. Jakarta: TIM.

Pantiawati, I. (2010). Bayi Dengan BBLR (Berat Badan Lahir Rendah). Yogyakarta: Nuha Medika.

Profil Dinas Kesehatan Propinsi Sulawesi Selatan. (2010). Profil Dinas Kesehatan Propinsi Sulawesi Selatan.

Puspitaningrum, E. M. (2018). Hubungan Status Gizi Ibu Hamil dengan Kejadian Berat Badan Lahir Rendah (BBLR) di RSIA Annisa Kota Jambi. Scientia Journal, 7(2), 1-7. https://doi.org/https:// doi.org/10.5281/scj.v7i2.67

Sari, D. P., \& Rahayu, W. (2017). Pengaruh kehamilan remaja terhadap bayi berat badan lahir rendah, 4(2), 56-66.

Supariasa, I. D. W., Bakri, B,. Fajar, I. (2001). Penilaian Status Gizi. Jakarta: Buku Kedokteran EGC.

Whitney, E. dkk. (2007). Makanan Kesehatan dan Kesehatan (Edisi Keti). United Serikat: Thomson.

Wiknjosastro. (2009). Ilmu Kebidanan. Jakarta: Yayasan Bina Pustaka Sarwono Prawirohardjo. 